\title{
Optimalisasi Pengelolaan Zakat: Implementasi dan Implikasinya dalam Perekonomian
}

\author{
Alifah Nur Fajrina \\ Universitas Pembangunan Nasional Veteran Jakarta \\ alifahfajrina@gmail.com \\ Farhan Rafi Putra \\ Universitas Pembangunan Nasional Veteran Jakarta \\ farhan.suhartoo@gmail.com \\ Annisa Suci Sisillia \\ Universitas Pembangunan Nasional Veteran Jakarta \\ sucisisillia1998@gmail.com
}

Received: August 6, 2020 | Accepted: August 8, 2020 | Published: August 10, 2020

\begin{abstract}
As an Islamic financial instrument, zakat has a very important and strategic role. The status of zakat as an obligation for Muslims, making zakat has great potential. The magnitude of this potential needs to be optimized so that the goals and wisdom of zakat can be realized. However, it is still recognized that the potential described has not been realized fully, with various obstacles encountered. This study examines theoretically related patterns and mechanisms of zakat management, both in terms of the sharia perspective and the implementation perspective in amil zakat institutions, and their impact on the economy. The results of the study explained that the effective management of zakat will make the contribution of zakat in the economy more optimal. Among the roles of zakat as a fiscal instrument in Islam, it is also an instrument of income redistribution. The role of zakat which is effective will contribute to overcoming various economic problems such as poverty, income inequality, to unemployment. Where through the zakat instrument a fair income distribution will be realized, so that it will increase the purchasing power of the people at the lower economic level, as well as increase the production capacity for entrepreneurs, as a result of increasing people's purchasing power.
\end{abstract}

Keywords: Zakat; Management Implementation; Zakah Impact; Economy

\begin{abstract}
Abstrak
Sebagai instrumen keuangan Islam, zakat memiliki peran yang sangat penting dan strategis. Status zakat sebagai kewajiban bagi umat Islam, menjadikan zakat memiliki potensi yang besar. Besarnya potensi tersebut perlu dioptimalkan agar tujuan dan hikmah zakat dapat terealisasi. Namun, masih diakui bahwa potensi yang tergambar belum dapat terealisasi sepenuhnya, dengan berbagai kendala yang dihadapi. Kajian ini mengkaji secara teoritis terkait pola dan mekanisme pengelolaan zakat, baik ditinjau dari perspektif syariah maupun perspektif implementatif di lembaga amil zakat, serta dampaknya dalam perekonomian. Hasil kajian menjabarkan bahwa pengelolaan zakat yang efektif akan menjadikan kontribusi zakat dalam perekonomian lebih optimal. Diantaranya peran zakat sebagai instrumen fiskal dalam Islam, juga merupakan instrumen redistribusi pendapatan. Peran zakat yang efektif akan berkontribusi dalam mengatasi berbagai permasalahan ekonomi seperti kemiskinan, kesenjangan pendapatan, hingga pengangguran. Dimana melalui instrumen zakat akan terwujud distribusi pendapatan yang berkeadilan, sehingga akan meningkatkan daya beli masyarakat pada tingkat ekonomi bawah, juga meningkatkan kapasitas produksi bagi para pengusaha, sebagai dampak dari peningkatan daya beli masyarakat.
\end{abstract}

Kata kunci: Zakat; Implementasi Pengelolaan; Implikasi Zakat; Perekonomian 


\section{PENDAHULUAN}

Dalam sistem ekonomi Islam, zakat termasuk salah satu sumber utama dana sosial untuk membantu kaum dhuafa. Zakat merupakan salah satu ibadah dalam Islam yang termasuk dalam rukun Islam ketiga dan bagian penting dalam menegakkan syariat Islam. Oleh karena itu, hukum zakat adalah wajib bagi umat muslim yang memenuhi ketentuan dan syarat-syarat tertentu. Perintah wajib membayar zakat sudah tertera secara jelas dalam al-quran dan hadits. Hal tersebut membuktikan bahwa zakat merupakan hal yang sangat penting dalam kehidupan perekonomian. Dimana zakat bertujuan untuk meningkatkan keadilan dan kesejahteraan masyarakat. Selain itu, zakat juga juga dapat membersihkan harta dan mensucikan jiwa pemilik harta dengan mengeluarkan sebagiannya untuk zakat.

Zakat bersifat wajib dan memiliki unsur paksaan (mandatory). Artinya, Seorang muslim yang memiliki harta yang telah memenuhi persyaratan zakat, jika melalaikan atau tidak mau menunaikannya, penguasa yang diwakili oleh para petugas zakat, wajib memaksanya (Fadhilah \& Widiastuti, 2018). Zakat yang dihimpun oleh Islam adalah bagi orang-orang yang mampu dan besarnya zakat tergantung pada nisabnya. Zakat didistribusikan kepada golongan masyarakat yang termasuk dalam delapan asnaf, diantaranya fakir, miskin, amil, mualaf, hamba sahaya, gharimin, fi sabilillah, dan ibnu sabil (Qardhawi, 2011).

Dalam perjalanan sejarahnya, zakat di berbagai negara memiliki pola pengelolaan yang berbeda-beda. Di zaman Nabi Muhammad SAW dan kekhalifahan Islam, zakat dipungut oleh negara. setelah runtuhnya khilafah Islamiyah. Banyak negara berpenduduk mayoritas Islam tidak campur tangan dalam memungut dan mendistribusikan zakat, termasuk Indonesia. Di kalangan ulama dan umat Islam juga terdapat perbedaan pendapat mengenai pemungutan zakat yang dilakukan oleh negara hingga dewasa ini. Namun, secara umum para ulama menilai bahwa zakat merupakan salah satu instrumen keuangan publik yang perlu dioptimalkan (BI, 2016).

Keuangan publik merupakan suatu kegiatan ekonomi yang penting untuk keberlangsungan hidup bernegara. Tanpa adanya pengaturan keuangan publik Islam yang baik maka negara sebagai institusi publik tidak akan menjalankan fungsinya dengan baik. Sistem keuangan publik Islam memiliki fungsi untuk menjaga tingkat alokasi sumber daya ekonomi pada tingkat yang minimum dengan menargetkan terpenuhinya kebutuhan dasar ekonomi masyarakat golongan bawah. Tingkat aktivitas ekonomi minimum dibuktikan dengan tingkat permintaan yang tidak sampai pada tingkat under-consumption. Disinilah terlihat pentingnya peran Pemerintah/Negara dalam menjaga tingkat alokasi sumber daya ekonomi. Pengentasan kemiskinan dan keberpihakan kepada kaum lemah 
merupakan salah satu misi ekonomi Islam. Misi ini tercermin dalam setiap cabangcabang ilmu dan praktik ekonomi Islam seperti di bidang perbankan, keuangan, bisnis, dan sebagainya. Termasuk di dalamnya adalah dalam kebijakan fiskal negara dalam hal ini adalah keuangan publik (Rini et al., 2017).

Dalam perjalanan sejarah Islam, berdasarkan perolehannya, sumber-sumber pendapatan negara tersebut dapat dikategorikan menjadi dua, yakni yang bersifat rutin (dawriyyah) seperti zakat dan pendapatan insidental (ghayr dawriyyah). Kewajiban zakat telah ditegaskan dalam syariat Islam yang tertuang dalam kerangka rukun Islam yang lima dimana zakat menduduki posisi rukun yang ketiga. Hal ini memberikan gambaran yang jelas bahwa dasar hukum zakat dalam Islam adalah syariat Islam, sehingga kewajiban zakat sifatnya melekat bagi setiap muslim yang memenuhi syarat-syarat menunaikan zakat sebagaimana dijelaskan dalam Al-Quran dan Sunnah (Chapra, 2001). Dengan kata lain, instrumen kebijakan fiskal pada waktu itu salah satunya adalah zakat. Instrumen zakat, pada dasarnya mengarah pada kepentingan yang sama yaitu kepentingan masyarakat dhuafa, selain penyediaan fasilitas publik lainnya.

Zakat mempunyai kedudukan utama dalam kebijakan fiskal dan keuangan publik pada masa awal Islam. Disamping sebagai sumber pendapatan negara Islam yang utama pada waktu itu, zakat juga mampu menunjang pengeluaran negara baik dalam bentuk government expenditure maupun government transfer. Zakat juga mampu mempengaruhi kebijakan ekonomi pemerintah Islam untuk meningkatkan kesejahteraan rakyat terutama kaum lemah (Rini et al., 2017).

Dalam struktur kebijakan fiskal konvensional, zakat belum menjadi salah satu instrumen. Pelaksanaan zakat selama ini lebih merupakan kegiatan masyarakat yang ingin mencucikan hartanya. Pengumpulan dan pendistribusiannya dilakukan secara tradisional dan bersifat end to end distribution. Hasilnya, zakat dibuat tidak berdaya menghadapi tingkat kemiskinan yang melanda negara-negara muslim termasuk di Indonesia.

Sekitar pertengahan tahun 1990-an, di Indonesia muncul lembagalembaga amil zakat yang mempunyai semangat untuk memperbaiki jalur pengumpulan dan distribusi zakat agar berjalan sebagaimana mestinya (Soekarni \& Muhammad, 2008). Pemerintah pun mengeluarkan perangkat perundangundangan berupa UU Nomor 38 tahun 1999 tentang pengelolaan zakat, dan diperbaharui melalui UU No. 23 Tahun 2011. Lembaga-lembaga zakat pun bermunculan. Manajemen dan jaringan lembaga-lembaga itu diperbaiki dan semakin baik sehingga dapat menjadi suatu gerakan tersendiri dalam pemberdayaan ekonomi umat.

Namun demikian potensi zakat yang sebenarnya belum dapat digali secara maksimal karena zakat masih dianggap sebagai sumbangan sukarela (voluntary donation) dan negara tidak dapat memaksa para wajib zakat untuk 
membayarkannya (Rohim, 2019). Padahal jika potensi tersebut lebih dioptimalkan, peran dan kontribusi zakat terhadap masalah ekonomi akan lebih signifikan. Selain itu, dengan mengembalikan zakat ke dalam kebijakan fiskal, potensi zakat yang sebenarnya akan dapat lebih dimaksimalkan.

Kedudukan zakat dalam kebijakan fiskal masih perlu dikaji secara lebih mendalam. Salah satunya adalah dengan melakukan penelusuran sejarah masyarakat muslim sejak masa Rasulullah SAW sampai sekarang. Penelusuran ini bertujuan untuk melihat lebih dekat kedudukan zakat dalam kebijakan fiskal Negara Islam awal, yaitu era Rasulullah SAW, Khulafa ar-Rasyidin, dan periodeperiode berikutnya. Sehingga akan dapat dijabarkan pola implementasi pengelolaan zakat dan implikasinya terhadap perekonomian.

\section{TINJAUAN PUSTAKA}

\section{A. Konsep Zakat}

Zakat berarti menumbuhkan, mensucikan, memperbaiki yang berarti pembersihan diri dari apa yang didapatkan setelah pelaksanaan kewajiban membayar zakat. Kata zakat itu sendiri menunjukkan bahwa harta yang dibelanjakan secara tidak bijaksana, baik untuk kepentingan diri sendiri maupun orang lain akan menimbulkan keburukan di masyarakat dengan cara menggalakkan industri - industri yang tidak produktif dan mewah sehingga melahirkan pertentangan dan perbedaan kelas. Hanya apabila harta dibelanjakan untuk hal - hal yang baik saja dapat menumbuhkan dan mensucikan masyarakat dari keburukan dengan mendorong pembangunan industri yang sehat, bermanfaat, dan produktif. Kata zakat seperti yang dijelaskan tersebut membentuk dua fungsi yang penting (Hafidhuddin, 2010).

Pertama, zakat akan mensucikan jiwa orang yang membayarnya dari sifat serakah dan sebaliknya mendorong untuk berderma dan membelanjakan harta untuk hal - hal yang baik. Kedua, zakat menjadikan masyarakat tumbuh dengan baik dan sehat. Zakat mencegah segala pengaruh yang menyebabkan terhambatnya pertumbuhan ekonomi, sebaliknya mendorong tercapainya kemajuan ekonomi.

Menurut Jumairi dan Wijaya (2011: 123) zakat dalam terminologi syariah diartikan sebagai kewajiban atas harta atau kewajiban atas sejumlah harta tertentu untuk kelompok tertentu dan dalam waktu tertentu. Kewajiban atas sejumlah harta tertentu, berarti zakat adalah kewajiban atas harta yang bersifat mengikat dan bukan anjuran. Kewajiban tersebut terkena kepada setiap muslim (baligh atau belum, berakal atau gila) ketika mereka memiliki sejumlah harta yang sudah memenuhi batas nisabnya. Kelompok tertentu adalah mustahik yang terangkum dalam delapan asnaf. 
Waktu untuk mengeluarkan zakat adalah ketika sudah berlalu setahun (haul) untuk zakat emas, perak, perdagangan dll, ketika panen untuk hasil tanaman, ketika memperolehnya untuk barang temuan (rikaz) dan ketika bulan Ramadhan sampai sebelum shalat 'Id untuk zakat fitrah. Islam telah mengajarkan hal ini kepada umat muslim untuk melaksanakan amalan zakat. Islam memandang bahwa kewajiban zakat dibebankan kepada mereka yang kaya.

Zakat merupakan salah satu rukun Islam yang wajib dikerjakan bagi seluruh umat Islam, dimana kewajibannya itu ditentukan dengan jelas dan tegas baik di dalam ayat-ayat al-quran, hadits maupun hasil ijma'. Karena sifatnya yang wajib tersebut, maka orang yang mengingkari dan tidak melaksanakan kewajiban berzakat sudah dianggap sebagai seorang kafir dan keluar dari Islam (Qardhawi, 2011). Ada beberapa hal yang menjadi ciri khas yang membedakan zakat di dalam Islam dengan zakat yang ada di dalam agama-agama lain.

1. Zakat dalam Islam bukan hanya merupakan suatu kebajikan dan perbuatan baik, tetapi merupakan salat satu fondamen (rukun) Islam yang utama. Orang yang tidak mau membayar zakat dinilai fasik dan orang yang mengingkari zakat wajib disebut kafir. Zakat bukan hanya merupakan kewajiban secara ikhlas atau sedekah tak mengikat, tapi merupakan kewajiban bila dipandang dari segi moral dan agama adalah suatu yang mutlak dilaksanakan.

2. Zakat merupakan hak fakir miskin di dalam kekayaan orang-orang kaya. Hak itu diterapkan langsung oleh pemilik kekayaan yang sebenarnya yaitu Allah SWT.

3. Zakat merupakan kewajiban yang sudah ditentukan, yang oleh agama sudah ditentukan nisab, besar, batas-batas, syarat-syarat, waktu dan cara pembayarannya sejelas-jelasnya.

4. Kewajiban membayar zakat tidak hanya diserahkan kepada seseorang, tapi juga harus disertai campur tangan dan menjadi tanggung jawab pemerintah dalam hal memungut dan mendistribusikannya, yaitu melalui para amil.

5. Negara mempunyai kewenangan memberi pelajaran atau menghukum siapa saja yang tidak bersedia membayar kewajibannya.

6. Zakat merupakan sarana ibadah bagi seorang muslim untuk mendekatkan diri kepada Allah serta membersihkan diri dan kekayaannya.

7. Sasaran zakat adalah orang-orang yang ditentukan, tidak boleh diserahkan kepada orang yang tidak berhak.

8. Zakat bertujuan untuk selama-lamanya, mencari penyebab kemiskinan itu dan mengusahakan agar orang-orang miskin itu mampu memperbaiki sendiri kehidupan mereka.

9. Zakat harus mampu mencapai tujuannya, baik tujuan spriritual, moral, sosial dan politik. 
Dari beberapa ciri khas zakat di atas, jelaslah bahwa zakat di dalam Islam merupakan suatu sistem baru yang berbeda dengan anjuran-anjuran dalam agama lain tentang kewajiban manusia untuk saling berbagi, dan tidak kikir. Zakat berbeda dari pajak dan upeti dan pajak yang dipungut justru dari orang-orang miskin untuk diberikan orang-orang kaya yang berbeda dalam tampuk kekuasaan.

Al-quran telah menjelaskan penentuan alokasi zakat, siapa yang berhak menerimanya, tetapi tidak dijelaskan apakah yang zakat itu harus diterima dalam bentuk uang, barang-barang konsumsi atau modal kerja. Hal ini menimbulkan pemikiran para ekonom, sehingga melahirkan ide agar zakat memberikan dampak yang lebih baik bagi para penerima. Sehingga zakat yang diberikan dapat lebih mengarah pada zakat produktif (Waluya, 2017).

Beberapa ahli ekonomi Islam menganggap zakat merupakan sejenis pajak karena zakat memenuhi beberapa persyaratan perpajakan. Sumbangan yang memenuhi persyaratan di bawah ini oleh para ahli ekonomi dianggap sebagai pajak, yaitu:

1. Pembayaran yang diwajibkan;

2. Tidak ada balasan atau imbalan; dan

3. Diwajibkan kepada seluruh masyarakat suatu negara (Fajarudin, 2019).

Zakat memenuhi persyaratan pertama dan kedua, sedangkan persyaratan ketiga tidak memenuhi. Pajak pemerintah merupakan beban yang tidak disukai banyak orang. Sebaliknya, zakat merupakan tanggung jawab agama yang dilaksanakan dengan penuh semangat untuk mencari ridha Allah.

Dalam pendistribusiannya, zakat disalurkan kepada delapan golongan yang telah disebutkan secara eksplisit di dalam al-quran. Delapan golongan tersebut dijabarkan oleh para ulama, diantaranya menurut ulama salaf dari mazhab syafi' sebagai berikut (Sabiq, 2009):

1. Fakir adalah orang yang tidak mempunyai harta dan usaha; atau mempunyai usaha atau harta yang kurang dari seperdua kecukupannya, dan tidak ada orang yang berkewajiban memberi belanjanya. Untuk bagian fakir, setengah bagiannya diberikan kepada mereka yang berperang di jalan Allah, setengah bagiannya lagi diberikan kepada fakir yang tidak ikut serta dalam perang seperti mereka yang menderita sakit lumpuh dan orang yang tidak bisa ikut berperang berdasarkan alasan syar'i. Bagian miskin, setengah diberikan kepada mereka yang menderita sakit dan tidak bisa berusaha, setengahnya lagi kepada mereka yang meminta-minta dan meminta makanan.

2. Miskin adalah orang yang mempunyai harta atau usaha sebanyak seperdua kecukupannya atau lebih, tetapi tidak sampai mencukupi. Yang dimaksud dengan kecukupan, cukup menurut umur biasa 62 tahun, maka mencukupi dalam masa tersebut dinamakan "kaya", ia tidak boleh diberi zakat, ini dinamakan kaya dengan harta. Adapun kaya dengan usaha, seperti orang 
yang mempunyai penghasilan tertentu tiap hari atau tiap bulan, maka kecukupannya dihitung setiap hari atau setiap bulan. Bagian miskin, setengah diberikan kepada mereka yang menderita sakit dan tidak bisa berusaha, setengahnya lagi kepada mereka yang meminta-minta dan meminta makanan.

3. 'Amil adalah semua orang yang bekerja mengurus zakat, sedang dia tidak mendapat upah selain dari zakat itu. Bagian amil zakat dilihat dari usahanya dan prestasinya dalam memungut zakat secara amanah dan 'iffah . Kemudian diberikan bagian zakat sesuai dengan tugas yang telah dijalankannya, dan sesuai dengan usahanya di dalam pengumpulan zakat, ataupun sejumlah yang diberikan oleh imam, berpedoman atas kerja yang dilakukan olehnya, atau sebesar biaya pulang pergi selama mengurusnya. Menurut Imam alMawardi, Allah menentukan gaji mereka berasal dari uang zakat, agar tidak ada lagi selain zakat yang diambil dari para muzakki (pembayar zakat). Jatah mereka diberikan kepada mereka dan besarnya sesuai gaji orang-orang selevel dengan mereka. Jika jatah mereka lebih banyak daripada orang-orang yang selevel dengan mereka, kelebihannya diberikan kepada penerima zakat yang lain. Jika jatah mereka lebih sedikit daripada gaji orang-orang yang selevel dengan mereka, kekurangannya diambilkan dari uang zakat menurut salah satu pendapat, atau diambilkan dari bait al-mâl (kas negara) menurut pendapat yang lain.

4. Muallaf adalah (a) orang yang baru masuk Islam, sedang imannya belum kuat. (b) Orang Islam yang berpengaruh dalam kaumnya yang masih kafir, dan diharapkan kalau dia diberi zakat, orang lain dari kaumnya akan masuk Islam. (c) Orang Islam yang berpengaruh terhadap kafir kalau dia diberi zakat, sehingga umat muslim akan terpelihara dari kejahatan kafir yang di bawah pengaruhnya. (d) Orang yang menolak kejahatan orang yang anti zakat.

5. Hamba sahaya yang dijanjikan oleh tuannya bahwa dia boleh menebus dirinya, hamba itu diberi zakat sekedar untuk memerdekakan dirinya. Menurut Imam Syafi'i dan Abu Hanifah, jatah budak diberikan kepada budak mukatib (budak dalam masa pembebasan dengan membayar sejumlah uang kepada tuannya). Mereka diberi sejumlah uang untuk membebaskan dirinya dari tuannya. Imam Malik berkata, "zakat untuk jatah budak digunakan untuk membebaskan budak."

6. Sedang besar zakat yang diberikan kepada gharimin (kelompok yang memiliki hutang) ialah sejumlah hutangnya asalkan untuk kebaikan dan bukan berlebih-lebihan, bahkan untuk kebutuhan yang sangat mendesak. Golongan ini dapat dikelompokkan menjadi tiga yaitu: (a) Orang yang berutang karena mendamaikan antara dua orang/pihak yang berselisih. (b) Orang yang berutang untuk kepentingan dirinya sendiri pada keperluan yang mubah atau 
yang tidak mubah, tetapi dia sudah tobat. (c) Orang yang berutang karena menjamin utang orang lain, sedang dia dan yang dijaminnya itu tidak dapat membayar utang itu. Dari pembagian ini, maka yang poin (b) dan (c) diberi zakat kalau dia tidak kuasa membayar utangnya, tetapi yang poin (a) diberi zakat, sekalipun dia kaya.

7. Fi sabilillah adalah tentara yang membantu dengan kehendaknya sendiri, sedang dia tidak mendapat gaji dan tidak pula mendapat bahagian dari harta yang disediakan untuk keperluan peperangan dalam barisan bala tentara. Orang ini diberi zakat, meskipun dia kaya, sebanyak keperluannya untuk masuk ke medan perang, seperti belanja, membeli senjata, kuda, dan alat peperangan lainnya.

8. Sedang besar zakat yang diberikan kepada ibnu sabil (orang yang sedang dalam perjalanan) ialah sejumlah biaya yang dapat dipakai untuk pulang ke kampung halamannya.

\section{B. Potensi Zakat di Indonesia}

Secara yuridis formal keberadaan zakat diatur dalam UU Nomor 23 tahun 2011 tentang Pengelolaan Zakat yang bertujuan untuk membantu golongan fakir dan miskin. Untuk mendorong terlaksananya undang-undang ini pemerintah telah memfasilitasi melalui Baznas yang bertugas untuk mengelola zakat, infaq, dan sedekah. Melihat dari sebagian besar penduduk Indonesia yang mayoritas menganut agama Islam, maka sesungguhnya zakat merupakan sektor ekonomi yang memiliki potensi untuk dikembangkan.

Zakat merupakan suatu aktivitas yang bertujuan duniawi dan terlebih juga ukhrawi. Distribusi pendapatan yang lebih merata, ekonomi yang lebih stabil dan alokasi sumber daya yang lebih berpihak pada pemenuhan kebutuhan hidup rakyat banyak, semua itu adalah dampak duniawi dari kegiatan zakat. Demikian juga zakat berkaitan dengan pahala, yaitu dimensi kehidupan akhirat (Rohim, 2018).

Disamping itu dampak untuk pengeluaran-pengeluaran lainnya seperti infaq, sadaqah dan wakaf, tercermin pada ayat berikut ini:

"Perumpamaan (nafkah yang dikeluarkan) oleh orang-orang yang menafkahkan hartanya di jalan Allah adalah seperti sebutir benih yang tumbuh tujuh tangkai, pada tiap-tiap tangkai seratus biji, Allah melipatgandakan (pahala) bagi siapa yang Dia kehendaki dan Allah Maha Luas (karunia-Nya) lagi Maha Mengetahui" (Q.S Al Baqarah [2]: 261).

Pengembangan potensi zakat diperlukan untuk mengoptimalkan peran zakat dalam perekonomian sebuah negara, terutama untuk mengatasi masalah kemiskinan, ketimpangan pendapatan, dan pengangguran. Penghimpunan potensi zakat dan pendistribusian yang bersifat produktif akan menggairahkan 
kembali perekonomian negara. Bahkan untuk Indonesia, optimalisasi peran zakat akan bisa menggerakkan sektor riil terutama usaha kecil menengah dan pertanian.

Faktor penting yang juga menjadi pendukung utama dalam mewujudkan zakat sebagai pilar perekonomian adalah wujudnya pelembagaan zakat yang amanah, profesional, dan mandiri. Sebab, penanganan keseluruhan terhadap zakat tidak mungkin dilakukan tanpa sebuah lembaga yang jelas.

Perkembangan pengelolaan zakat khususnya di Indonesia telah memperlihatkan sebuah kemajuan yang berarti, sejak dikeluarkannya UU No. 23 Tahun 2011. Peraturan pemerintah terhadap lembaga pengelolaan zakat juga telah menimbulkan gairah baru dalam menjalankan optimalisasi zakat. Dikeluarkanya UU dan Peraturan Pemerintah terhadap pengelolaan zakat merupakan angin segar terhadap pengembangan potensi zakat di masa datang. Respon terhadap kebijakan ini haruslah disikapi dengan kesiapan secara menyeluruh terhadap sistem zakat. Kesiapan institusi zakat, profesional terhadap pengelolaan dan akuntabilitas dalam pelaporan, serta dasar syariah sebagai wujud pengelolaan adalah hal-hal penting yang harus diperhatikan.

Setiap tahun, penghimpunan zakat nasional mengalami pertumbuhan ratarata 30,55 persen. Pada 2016, zakat yang berhasil dihimpun organisasi pengelola zakat baik Baznas maupun LAZ adalah sebesar Rp 5.017,29 miliar, dan meningkat menjadi Rp 6.224,37 miliar pada 2017 dan Rp8,1 miliar pada 2018. Di tahun 2019, potensi zakat di seluruh Indonesia diperkirakan mencapai Rp233,6 T. Di antara provinsi lainnya di Indonesia, Jawa barat merupakan salah satu provinsi yang memiliki potensi zakat tertinggi yakni sebesar Rp26,845 M (Puskas Baznas, 2019b).

Meskipun pada saat ini potensi zakat tersebut belum terealisasi, Baznas berusaha menyalurkan dana zakat yang terkumpul melalui beberapa program pemberdayaan di beberapa bidang seperti keagamaan, ekonomi, sosial, dan pendidikan. Penyaluran zakat-nya pun sesuai dengan delapan asnaf. Pada kenyataannya, dana zakat yang berhasil dihimpun dari masyarakat masih jauh dari potensi yang sebenarnya. Sebagai perbandingan, dana zakat yang berhasil dikumpulkan oleh lembaga-lembaga pengumpul zakat baru mencapai beberapa puluh milyar. Itu pun bercampur dengan infak, hibah, dan wakaf. Potensi yang sangat besar itu akan dapat dicapai dan disalurkan kalau pelaksanaannya dilakukan oleh negara melalui departemen teknis pelaksana.

Zakat mempunyai potensi untuk turut membantu pencapaian sasaran pembangunan nasional. Dana zakat yang sangat besar sebenarnya cukup berpotensi untuk meningkatkan taraf hidup masyarakat jika disalurkan secara terprogram dalam rencana pembangunan nasional. Dalam periode tertentu, suatu negara membuat rencana pembangunan di berbagai bidang sekaligus perencanaan anggarannya. Potensi zakat yang cukup besar dan sasaran distribusi zakat yang jelas seharusnya dapat sejalan dengan rencana pembangunan nasional 
tersebut. Agar dana zakat dapat disalurkan secara tepat, efisien dan efektif sehingga mencapai tujuan zakat itu sendiri seperti meningkatkan taraf hidup masyarakat. Pengumpulan dan pendistribusian zakat yang terpisah-pisah, baik disalurkan sendiri maupun melalui berbagai charity membuat misi zakat agak tersendat. Harus diakui bahwa berbagai lembaga OPZ telah berbuat banyak dalam pengumpulan dan pendistribusian dana zakat dan telah banyak hasil yang dapat dipetik. Namun, hasil itu dapat ditingkatkan kalau pengumpulan dan pengelolaannya itu dilakukan oleh negara melalui perangkat perangkatnya.

\section{PEMBAHASAN}

\section{A. Zakat sebagai Pengeluaran Negara}

Kebijakan pemerintah dalam pengelolaan pengeluaran keuangan negara tercermin dalam anggaran pendapatan dan beelanja negara (APBN) yang setiap tahun direncanakan dan disusun. APBN berisi daftar sistematis dan terperinci yang memuat perencanaan penerimaan dan pengeluaran negara selama satu tahun anggaran (1 Januari-31 Desember). APBN merupakan instrumen dalam mengatur pendapatan dan pengeluaran negara dalam rangka membiayai pelaksanaan kegiatan pemerintah dan pembangunan, mencapai pertumbuhan ekonomi, meningkatkan pendapatan nasioanl, mencapai stabilitas perekonomian, dan menentukan arah serta prioritas pembangunan secara umum. APBN memiliki fungsi antara lain otoritasi, perencanaan, pengawasan, alokasi, distribusi, dan stabilisasi. Semua penerimaan yang masuk kas negara dan pengeluaran yang menjadi kewajiban negara dimasukan ke dalam APBN untuk satu tahun anggaran. Surplus penerimaan negara dapat digunakan untuk membiayai pengeluaran anggran negara pada tahun berikutnya. (Priyono, 2017)

Dalam catatan sejarah islam, tidak dikenal istilah APBN, tetapi ketiadaan tata tidak berati menghilangkan makna dan aplikasi yang sesungguhnya. Dalam Islam terdapat suatu konsep yang mewujud dalam bentuk lembaga yang tak terpisahkan dalam struktur pemerintahan untuk mengatur penerimaan dan pengeluaran negara yang dikenal dengan baitul mal. Baitul mal dalam pengertian ini, telah dipraktikan dalam sejarah Islam sejak masa Rasullah SAW, kemudian diteruskan oleh para khalifah sesudahnya. Gagasan konsep baitul mal yang ideal disusun dengan merujuk pada ketentuan syariah, baik dalam hal sumber-sumber pendapatan maupun dalam hal pengelolaan pengeluaraanya. (Priyono, 2017)

Pengelolaan zakat oleh negara dalam beberapa tinjauan para ulama ternyata memiliki dampak positif yang lebih besar dibandingkan bila zakat disalurkan sendiri-sendiri oleh muzaki. Walaupun menyalurkan zakat secara langsung memang sah ditinjau dari hukum syariah, tetapi menyalurkan zakat melalui lembaga pengelola zakat yang ditunjuk yang didirikan oleh negara akan jauh lebih efektif daripada menyalurkannya secara orang per orang. 
Ada beberapa keuntungan yang bisa didapatkan dengan menyalurkan zakat kepada lembaga pengelola zakat yang tidak akan diperoleh dengan membayarkan secara langsung oleh muzaki kepada mustahik, yaitu:

1. Menjamin kepastian dan disiplin muzaki dalam membayar zakat

2. Untuk menjaga perasaan rendah diri pada mustahik.

3. Memperlihatkan syiar Islam

4. Untuk mencapai efisiensi dan efektifitas, serta sasaran yang tepat dalam penggunaan dana zakat menurut skala prioritas

5. Dapat digunakan untuk kemaslahatan umat Islam secara umum

Jika zakat diserahkan secara langsung dari muzaki kepada mustahik, meskipun secara hukum syariah adalah sah, akan tetapi disamping akan terabaikanya hal-hal di atas, juga hikmah dan fungsi zakat, terutama yang berkaitan dengan kesejahteraan umat secara umum, akan sulit diwujudkan. Di samping keutamaan yang telah disebutkan, penyerahan zakat kepda petugas zakat merupakan hal yang biasa dilakukan dan dicontohkan oleh Rasulullah SAW dan para sahabat sesudahnya. Bahkan para ulama sesudahnya pun tetap mewajibkan penyerahan pengurusan dan pengeolaan zakat kepada petugas.

Mengenai metode pendistribusian zakat, Abu 'Ubaid dalam kitabnya alAmwal memaparkan bahwa penyerahan zakat harta kepada para penguasa dan kemudian membagikanya secara langsung merupakan pendapat yang harus dianut dan diaplikasikan (Chaniago, 2015). Hal ini khusus berlaku hanya pada zakat emas dan perak. Hal ini sebagaimana hadits yang berbunyi sebagai berikut:

Dari Ibnu Umar, ia berkata, "Selama para pemimpin itu masih menegakkan shalat, maka serahkanlah zakat harta itu kepada mereka."

Dari Ibnu Umar, ia berkata, "Serahkanlah zakat harta itu kepada para orang yang telah dilantik Allah sebagai pemimpin di kalangan kalian. Barangsiapa yang melakukan kebaikan, maka kebaikan itu untuk dirinya sendiri. Barangsiapa yang melakukan kejahatan dosa, maka dosanya tetap akan kembali kepada dirinya sendiri juga."

Dalam kitabnya Abu 'Ubaid berkata bahwa seluruh dana zakat dibagikan secara merata kepada seluruh asnaf apabila mampu untuk dilakukan. Cara pembagian seperti ini diwajibkan kepada pemimpin jika harta kaum muslimin melimpah ruah, sebagaimana hadits berikut:

Dari Ibrahim, ia berkata, "Apabila zakat harta itu banyak, maka bagikanlah secara merata di antara asnaf yang delapan. Apabila harta zakat itu sedikit, maka berikanlah kepada satu asnaf saja."

Adapun tentang pembagian hanya kepada sebagian asnaf saja, maka hal ini dibolehkan berdasarkan kepada hadits yang telah diriwayatkan dari Rasulullah, ketika beliau menerangkan tentang zakat. Dalam hadits tersebut, beliau hanya menyebutkan satu golongan saja yaitu golongan fakir. 
Dengan demikian, seorang pemimpin diberikan kebebasan memilih antara membagikan zakat harta secara merata kepada seluruh asnaf yang delapan atau hanya memberikannya kepada sebagian asnaf saja, apabila yang demikian itu berdasarkan kepada ijtihad kemaslahatan, tidak ada unsur nepotisme dan jauh dari penyelewengan kebenaran. Demikian juga selain pemimpin, bahkan ia memiliki kebebasan memilih yang lebih luas.

Dalam konteks pendistribusian zakat di Indonesia, terdapat beberapa hal yang perlu diperhatikan agar pendistribusian dapat dijalankan secara efektif. Pertama, dengan cara memaksimalkan potensi amil zakat baik dari segi kuantitas dan kualitasnya. Tentu saja distribusi yang efektif haruslah dimulai dari teknik pengumpulan yang efektif. Amil zakat seharusnya dibagi tugasnya dari tingkat terendah ke tingkat tertinggi. Amil dapat mengumpulkan zakat dari tingkat RT terlebih dahulu dan menyalurkannya di antara lingkungan RT tersebut terlebih dahulu. Jika di lingkungan RT tersebut sudah tidak ada lagi mustahiq, maka disalurkan ke tingkat RW dan seterusnya (Canggih, 2017).

Seorang amil juga harus lebih aktif dalam pengumpulan dan penyaluran dana zakat, jangan sampai para muzakki dan mustahiq yang berinisiatif sendiri untuk memberi dan meminta dana zakat. Cara ini lebih efektif dan lebih tepat sasaran karena resiko pemalsuan identitas para mustahiq dapat diminimalisir karena pendataan yang jelas dan akurat dari lingkungan yang mudah didata terlebih dahulu dalam hal ini RT.

Kedua, dukungan dari muzakki dan mustahiq itu sendiri sangat diperlukan agar zakat dapat diterima dan disalurkan sebagaimana mestinya serta efektif. Ulama dan cendikiawan muslim pun juga berperan dalam mengedukasi masyarakat dalam membangun kesadaran seberapa pentingnya zakat dalam kehidupan ekonomi masyarakat Islam.

Ketiga, semua hal di atas tidak dapat berjalan sebagaimana mestinya kecuali ada dukungan dari pemerintah dengan membuat regulasi tentang zakat yang lebih jelas, baik dari segi pengumpulan serta penyalurannya dalam sistem perundang-undangan Indonesia yang sah.

\section{B. Zakat dan Ekonomi Makro}

Berdasarkan kemampuan membayar zakat, masyarakat muslim dapat kita kelompokkan menjadi tiga golongan; pertama, golongan masyarakat muzakki yaitu golongan masyarakat pembayar zakat. Kedua, golongan masyarakat nonmustahik dan non-muzakki yaitu golongan yang bukan penerima ataupun pembayar zakat (golongan middle income). Ketiga, golongan masyarakat mustahik yaitu golongan masyarakat penerima zakat. Terkait pembagian tersebut, zakat harus didistribusikan secara proporsional dengan standar pemenuhan kebutuhan hidup mustahik. Tepenuhinya kebutuhan hidup minimal diharapkan menjamin 
seluruh masyarakat Islam dapat menjalankan secara leluasa segala kewajibannya sebagai hamba Allah, tanpa perlu ada hambatan-hambatan yang mungkin memang di luar kemampuannya. Zakat memungkinkan perekonomian terus berjalan pada tingkat yang minimum (Nasution, 2006).

Dalam analisa makro ekonomi, kegiatan belanja (konsumsi) merupakan variabel yang sangat positif bagi kinerja perekonomian (economic growth). Ketika perekonomian mengalami stagnasi, seperti terjadi penurunan tingkat konsumsi atau bahkan sampai pada situasi underconsumption, kebijakan utama yang diambil adalah bagaimana dapat menggerakkan ekonomi dengan meningkatkan daya beli masyarakat. Sehingga dapat dikatakan bahwa kemampuan daya beli masyarakat menjadi sasaran utama dari setiap kebijakan ekonomi (Puskas Baznas, 2019a).

Implementasi konsep dan sistem zakat akan dapat mengurangi pengangguran dalam perekonomian melalui tiga mekanisme. Pertama, implementasi zakat itu sendiri membutuhkan tenaga kerja. Kedua, perubahan golongan mustahik yang awalnya tidak memiliki akses pada ekonomi menjadi golongan yang lebih baik secara ekonomi, yang tentu saja meningkatkan angka partisipasi tenaga kerja. Ketiga, multiplier effect dari munculnya usaha/industri pendukung yang akan menambah lapangan kerja. Dengan kata lain dengan konsep dan sistem zakat dapat membantu mengurangi pengangguran dalam perekonomian sehingga daya beli masyarakat tetap stabil (Azharsyah Ibrahim, 2011).

Umer Chapra menyatakan bahwa zakat adalah sebuah langkah kemandirian sosial yang diambil dengan dukungan penuh agama untuk membantu orang-orang miskin yang tidak dapat memenuhi kebutuhan dasar mereka sendiri. Selain itu, zakat juga harus memberikan pengaruh yang bermanfaat bagi negara, misalnya sebagai sumber investasi. Redistribusi zakat dari semua kekayaan akan mendorong pembayar zakat untuk mencari pendapatan dari harta mereka agar dapat membayar zakat tanpa mengurangi harta tersebut. Dalam Islam, penimbunan harta dilarang, sehingga meningkatkan investasi yang berarti menyumbangkan kemakmuran (Chapra, 2001).

\section{Zakat sebagai Instrumen Fiskal}

Kebijakan fiskal atau yang sering disebut sebagai "politik fiskal" (fiscal policy) bisa diartikan sebagai tindakan yang diambil oleh pemerintah dalam bidang anggaran belanja negara dengan maksud untuk mempengaruhi jalannya perekonomian. Anggaran belanja negara terdiri dari penerimaan dan pengeluaran. Kebijakan fiskal adalah kebijakan yang diambil pemerintah untuk membelanjakan pendapatannya dalam merealisasikan tujuan-tujuan ekonomi. Adapun dalam Islam kebijakan fiskal dan anggaran ini bertujuan untuk 
mengembangkan suatu masyarakat yang didasarkan atas distribusi kekayaan berimbang dengan nilai-nilai material dan spiritual pada tingkat yang sama.

Upaya pengintegrasian zakat ke dalam kebijakan fiskal negara adalah dengan melakukan rekonstruksi sejarah terhadap pelaksanaan zakat pada masa awal Islam. Pada masa awal Islam, zakat merupakan 'pungutan' wajib yang ditarik dari masyarakat untuk membiayai pengeluaran negara pada waktu itu. Dalam perkembangannya, zakat mengalami kestatisan karena terlanjur dibakukan sehingga tidak dapat beradaptasi dengan perkembangan perekonomian umat. Akibatnya, untuk pembiayaan kebutuhan negara ditariklah pajak dari masyarakat karena bersifat dinamis dan dapat diatur pelembagaannya oleh pemerintah sesuai dengan tujuan-tujuan pembangunan ekonomi yang telah disusun pemerintah. Pengembalian zakat ke khittah awalnya ini dapat dilakukan dengan keberanian merumuskan kembali konsep zakat dalam Islam (Nuruddin, 2006).

Dengan terintegrasinya zakat ke dalam kebijakan fiskal tersebut, maka pemerintah dapat menetapkan kebijakan fiskal yang sama-sama menguntungkan, baik bagi umat Islam maupun bagi negara. Hal ini pada gilirannya akan menyebabkan pergeseran berbagai ketentuan dalam hukum zakat tradisional. Pengaruh kebijakan fiskal modern terhadap hukum zakat terjadi pada subyek dan obyek, tarif dan sasaran pendistribusian zakat. Subyek zakat dalam kebijakan fiskal juga termasuk badan hukum di samping perorangan. Sedangkan pengaruh kebijakan fiskal terhadap obyek zakat adalah bahwa jenis kekayaan yang dikeluarkan zakatnya tidak terbatas pada jenis-jenis harta yang telah ditentukan oleh Rasulullah SAW saja, tetapi juga meliputi berbagai jenis kekayaan lainnya menurut kebijakan pemerintah. Pengaruh kebijakan fiskal lainnya adalah dalam hal tarif atau prosentase (rasio) dan nisab zakat menjadi tidak tetap (baku). Tarif yang ditetapkan mungkin saja berupa tarif proporsional, tarif agresif, dan tarif progresif sesuai dengan kebijakan fiskal yang akan dicapai oleh pemerintah. Sedangkan pengaruh terhadap sasaran pendistribusian zakat adalah perluasan makna asnaf delapan yang telah ditetapkan dalam al-quran. Perluasan makna tersebut bertujuan untuk terpenuhinya pengeluaran pemerintah dalam rangka mencapai kesejahteraan masyarakat.

Selain itu, zakat juga berperan sebagai salah satu instrumen redistribusi pendapatan dan kekayaan. Distribusi pendapatan dalam Islam merupakan penyaluran harta yang ada, baik yang dimiliki oleh pribadi atau umum (publik) kepada pihak yang berhak menerima dengan tujuan untuk meningkatkan kesejahteraan masyarakat, sesuai dengan yang ada dalam Islam. Fokus dari distribusi pendapatan dalam Islam adalah proses pendistribusiannya dan bukan output dari distribusi tersebut (Brodjonegoro, 2012). Ada dua peran zakat dalam meningkatkan keadilan distribusi pendapatan: 
1. Zakat berfungsi untuk mengurangi tingkat pendapatan yang siap dikonsumsi (disposable income) oleh kelompok masyarakat kaya (muzakki). Oleh karena itu, pengimplementasian zakat diharapkan akan mampu mengerem tingkat konsumsi orang kaya. Hal ini pada gilirannya akan memiliki dampak yang positif, yaitu menurunnya dampak meningkatkan harga-harga komoditas.

2. Zakat berfungsi sebagai media transfer pendapatan sehingga mampu meningkatkan daya beli masyarakat miskin. Dalam hal ini diharapkan dengan menerima zakat, maka segmen masyarakat miskin akan meningkat daya belinya sehingga mampu berinteraksi dengan segmen masyarakat kaya.

Selain kedua peran tersebut, zakat juga dapat berperan sebagai penstabil otomatis (automatic stabilizers). Ketika perekonomian dalam masa ekspansi atau boom, kebutuhan untuk mencairkan dana zakat akan berkurang atau dengan kata lain pencairan dana zakat lebih sedikit karena pada masa itu lapangan kerja meningkat dan pendapatan masyarakat juga meningkat, sehingga jumlah mustahik berkurang. Pada masa ekspansi ini zakat berperan sebagai instrumen anti inflasi otomatis, karena ekspansi ekonomi cenderung mendorong peningkatan pendapatan dan pada gilirannya mendorong permintaan agregat dan inflasi. Sebaliknya, pada masa resesi, kebutuhan untuk pencairan dana zakat meningkat karena pada masa itu lapangan kerja berkurang, pendapatan masyarakat menurun, sehingga distribusi penyaluran/penerimaan zakat yang lebih tinggi kepada orang miskin. Dengan kata lain, dana zakat pada masa resesi mampu menciptakan efek ekspansif bagi perekonomian (Brodjonegoro, 2012).

\section{Implikasi Zakat terhadap Perekonomian}

Pengaruh zakat dalam perekonomian dapat meningkatkan kapasitas dan daya beli mustahik, mendorong investasi dengan pengurangan akumulasi modal yang tidak produktif, sehingga secara keseluruhan akan meningkatkan produktifitas perusahaan yang berimbas pada penyerapan tenaga kerja serta pendapatan Negara dari pajak perusahaan. Dalam konteks pengelolaan zakat yang dilakukan oleh Baznas, zakat disalurkan dalam bentuk bantuan konsumtif dan bantuan produktif. Dari segi bantuan konsumtif diharapkan akan meningkatkan konsumsi mustahik secara keseluruhan. Sedangkan dari segi bantuan produktif diharapkan akan meningkatkan kapasitas produksi mustahik dan pada akhirnya akan meningkatkan output nasional yang tergambar dalam Produk Domestik Bruto (PDB) (Puskas, 2018).

Secara ekonomi, zakat membentuk suatu perilaku kepada para pelaku ekonomi yaitu konsumen dan produsen. Zakat memiliki peran yang sangat signifikan dalam perilaku konsumsi dan produksi. Fungsi harta sebagai pokok kehidupan memiliki pengaruh pada perilaku manusia dalam produksi dan konsumsi dari masing-masing harta yang dimiliki. Pokok kehidupan bermakna bahwa harta yang dimiliki itu dapat menjamin berlangsungnya kehidupan secara 
luas yang bukan hanya terfokus secara pribadi. Dalam sistem ekonomi Islam perilaku manusia dalam menyikapi harta itu, dengan memaknai bahwa harta bukanlah tujuan melainkan hanya alat untuk menumpukkan pahala demi tercapainya kebahagiaan dunia dan akhirat. Selain itu Islam memang memandang bahwa segala yang ada di dunia ini adalah milik Allah SWT. Sehingga apa yang dimiliki manusia itu hanyalah amanah. Dan nilai amanah itu yang akan menuntut manusia untuk menyikapi harta dengan baik dan benar.

Di sisi lain, zakat merupakan instrumen dalam Islam yang efektif dalam mengentaskan kemiskinan. Sehingga salah satu solusi yang dapat dilakukan adalah mensosialisasikan kepada umat Islam tentang perhitungan zakat dengan benar dan mengajar umat Islam menunaikan kewajibannya tersebut. Sehingga Pemerintah harus berupaya memberikan mekanisme pembayaran yang mudah secara memadai dan optimal, meningkatkan transparansi, dan sosialisasi kepada seluruh masyarakat muslim di Indonesia. Oleh karena itu, zakat sangat berpotensi di Indonesia.

Dalam hal mengenai zakat dan ekonomi tentu akan sangat erat diantara keduanya. Zakat memberikan dampak positif terhadap kesejahteraan masyarakat, karena zakat didistribusikan kepada masyarakat golongan mustahik, yang akan terjadi hubungan harmonis antara golongan kaya dan fakir miskin. Disisi lain zakat merupakan income bagi kelompok masyarakat dhuafa yang membuat kelompok tersebut dapat memiliki daya beli (purchasing power). Dengan kata lain, purchasing power yang dimiliki kelompok dhuafa dari distribusi zakat, mendorong kelompok masyarakat ini tidak tersisih dari aktivitas ekonomi dan selalu memiliki akses pasar untuk mendapatkan sumber daya ekonomi yang menjadi kebutuhannya.

Dari aspek ekonomi, zakat bermanfaat untuk menghindari penumpukan harta pada segelintir orang, mendistribusikan harta secara lebih adil dan merata, menyejahterakan kaum lemah dan diharapkan menghasilkan tata ekonomi yang harmoni dan pertumbuhan ekonomi yang baik. Selain itu ada dimensi spiritual sebagai tujuan, yaitu penjagaan keimanan umat atau masyarakat secara luas maupun penjagaan aliran sumber daya ekonomi atau distribusi kekayaan dan pendapatan dan pendapatan sektor keuangan publik dan sosial pada hakikatnya bertujuan menyediakan kebutuhan dasar umat atau masyarakat agar mereka dapat menunaikan kewajibannya kepada Tuhan (menjaga keimanan). Dalam konteks keseluruhan sistem ekonomi Islam, zakat memiliki peran sebagai berikut. (Juhro \& dkk, 2019)

1. Memenuhi kebutuhan dasar masyarakat, seperti memenuhi kebutuhan makanan, pakaian, tempat tinggal, kesehatan, dan pendidikan.

2. Mendukung kemandirian, untuk melatih keterampilan kerja, mengatasi pengangguran dan meningkatkan pendidikan atau keahlian (kompetensi) sehingga mampu bekerja dan mendapatkan penghasilan. 
3. Mendukung pengembangan ekonomi melalui dukungan bisnis pada level sosial dan semi komersial, untuk pengembangan kewirausahaan, memberikan modal usaha, asistensi usaha dan penguatan usaha.

4. Memenuhi kebutuhan sekunder yang penting, untuk melakukan pembelaan hukum, pelestarian lingkungan, dakwah dan advokasi untuk mengurangi kemiskinan dan menolong orang miskin.

Dalam pemberdayaan ekonomi, kedudukan zakat adalah menumbuhkan dan mendukung pengembangan usaha mikro dan kecil terutama pada level sosial. Hal tersebut akan meningkatkan frekuensi perputaran arus barang dan jasa yang memberikan efek ganda secara luas akan berdampak pada pertumbuhan ekonomi makro. Zakat akan dapat memberikan dampak yang lebih luas dan menyentuh semua aspek kehidupan, apabila pendistribusian zakat lebih diarahkan pada kegiatan yang bersifat produktif.

Para ulama seperti Imam Syafi'i, an-Nasa'i, dan lainnya menyatakan bahwa jika mustahik zakat memiliki kemampuan untuk berdagang, selayaknya dia diberi modal usaha yang memungkinkannya memperoleh keuntungan yang dapat memenuhi kebutuhan pokoknya (Hafidhuddin, 2005). Demikian juga jika mustahik tersebut memiliki ketrampilan tertentu, maka akan diberikan peralatan produksi yang sesuai dengan pekerjaannya. Jika mustahik tidak bekerja dan tidak memiliki keterampilan tertentu, menurut Imam Syamsuddin ar-Ramli, mustahik akan diberikan jaminan hidup dari zakat, misalnya dengan cara ikut menanamkan modal (dari uang zakat tersebut) pada usaha tertentu, sehingga mustahik tersebut memiliki penghasilan dari perputaran zakat itu.

Dalam Kitab Fiqih Zakat (Qardawi, 2000), bahwa tujuan dan dampak zakat bagi si penerima (mustahik) antara lain:

1. Zakat akan membebaskan si penerima dari kebutuhan, sehingga dapat merasa hidup tentram dan dapat meningkatkan khusyu ibadat kepada Tuhannya.

2. Zakat menghilangkan sifat dengki dan benci. Karena sifat ini akan melemahkan produktifitas. Islam tidak memerangi penyakit ini dengan semata-mata nasihat dan petunjuk, akan tetapi mencoba mencabut akarnya dari masyarakat melalui mekanisme zakat, dan menggantikannya dengan persaudaraan yang saling memperhatikan satu sama lain.

Adapun tiga hal penting yang harus mendapatkan penekanan upaya meningkatkan efektifitas dan kemanfaatan pendistribusian zakat, yaitu: Pertama, prioritas target distribusi zakat. Distribusi zakat sudah ditentukan hanya untuk delapan ashnaf. Hal tersebut dijelaskan bahwa fakir dan miskin sebagai kelompok pertama dan kedua dalam daftar penerimaan zakat, dikarenakan menunjukkan bahwa mengatasi masalah kemiskinan merupakan tujuan utama zakat. 
Kedua, bentuk pendistribusian zakat yang sesuai. Kadar zakat untuk fakir miskin tidak ditentukan menurut besarnya dana zakat yang terkumpul. Hal ini karena tujuan zakat adalah memberikan tingkat hidup yang layak sebagai seorang Muslim dengan cara memampukan mustahik untuk menghidupi dirinya sendiri dengan kemampuan yang dimilikinya.

Ketiga, menyesuaikan dengan kondisi lokal dan perkembangan terkini. Lembaga zakat perlu untuk memikirkan bentuk pendayagunaan zakat yang sesuai dengan kondisi dan kebutuhan masyarakat lokal serta perkembangan pemikiran tentang pemberdayaan ekonomi masyarakat. Sebagai misal, dalam kondisi bencana alam, distribusi zakat semestinya tidak hanya dalam bentuk cash transfer namun juga bisa dalam bentuk cash for work.

Agar pendistribusian dana zakat tepat sasaran yakni membangun ekonomi masyarakat supaya pada masa-masa yang akan datang tidak lagi menjadi orangorang yang berhak menerima zakat (mustahik), melainkan berubah menjadi orang-orang yang berkewajiban mengeluarkan zakat (muzakki), maka dilakukan program amil zakat yang dikembangkan dengan program Zakat Community Development (ZCD) yakni pengembangan komunitas secara komprehensif dengan mengintegrasikan aspek ekonomi dan aspek sosial (pendidikan, kesehatan, agama, lingkungan, dan aspek sosial lainnya) yang pendanaan utamanya bersumber dari zakat, infaq, dan sedekah sehingga terwujud masyarakat sejahtera dan mandiri (BAZNAS, 2013)

Motif konsumsi dalam Islam pada dasarnya adalah mashlahah, kebutuhan dan kewajiban. Aktivitas konsumsi juga bertujuan dalam meningkatkan ibadah dan keimanan kepada Allah SWT. Dalam membahas perilaku konsumsi dari individu muslim, karakteristik zakat sudah terlihat memiliki pengaruh positif terhadap angka konsumsi. Karena angka konsumsi sangat bergantung dengan distribusi zakat. Semakin banyak para mustahik yang menerima distribusi zakat, maka daya beli mustahik menjadi meningkat dan angka konsumsi mengalami peningkatan pula. Jadi dapat dikatakan bahwa pembahasan zakat dan kaitannya dengan makro ekonomi tidak dapat dipisahkan dari fungsi utama zakat sebagai variabel untuk peningkatan sisi permintaan dari sistem ekonomi (Sakti, 2007). Pengaruh zakat terhadap konsumsi didasarkan pada empat faktor yaitu:

1. Adanya perbedaan nilai marginal prospensity to consume antara golongan kaya dengan golongan miskin.

2. Jumlah golongan miskin sebagai penerima zakat cukup banyak,

3. Besarnya dana zakat yang disalurkan kepada golongan miskin, dan

4. Metode pendistribusian zakat yang digunakan seperti bantuan uang tunai atau barang (barang konsumsi atau barang modal). Pengaruh zakat terhadap konsumsi agregat dapat dijelaskan melalui fungsi konsumsi makro.

Fungsi konsumsi makro Islami diturunkan dari fungsi konsumsi mikro dua agen dalam ekonomi pada masyarakat muslim yaitu pembayar zakat (muzakki) dan penerima zakat (mustahik). Melalui golongan masyarakat penerima 
(mustahik) dan pembayar (muzakki), zakat memiliki peran dalam mendorong kinerja ekonomi. Menurut Kahft, zakat yang diterima oleh mustahik akan meningkatkan konsumsinya yang tentu kemudian meningkatkan agregat permintaan secara makro. Sementara itu, pada pihak muzakki, zakat akan meningkatkan rasio simpanan mereka, dengan asumsi bahwa tiap individu akan mempertahankan tingkat kekayaannya.

Kegiatan produksi dalam perspektif ekonomi Islam adalah terkait dengan manusia dan eksistensinya dalam aktivitas ekonomi, produksi merupakan kegiatan menciptakan kekayaan dengan pemanfaatan sumber alam oleh manusia. Berproduksi lazim diartikan menciptakan nilai barang atau menambah nilai terhadap sesuatu produk, barang dan jasa yang diproduksi itu haruslah hanya yang dibolehkan dan menguntungkan (yakni halal dan baik) menurut Islam (Haneef, 2010).

Pada sisi produksi, zakat pada hakikatnya menjaga transaksi di pasar agar barang hasil produksi terus dapat diserap oleh pasar. Lebih lanjut Monzer Kahf (1999), mengungkapkan bahwa zakat memiliki pengaruh yang positif pada tingkat tabungan dan investasi. Peningkatan tabungan akibat peningkatan pendapatan akan menyebabkan tingkat investasi juga meningkat. Karena jika tidak diinvestasikan, angka tabungan yg terus meningkat tersebut, jika sampai nishab akan dikenakan zakat. Jadi banyak yg melakukan investasi dari dana tabungannya agar hartanya tidak mencapai nishab. Metode untuk menginvestasikan tabungan adalah qard al-hasan yang sangat dianjurkan oleh Islam. Anjuran ini menjadi motivasi tersendiri bagi masyarakat Muslim untuk meminjamkan harta dan kekayaannya kepada produsen.

Disamping itu kahf juga mengungkapkan bahwa zakat cenderung mengurangi atau menurunkan resiko kredit macet, karena salah satu alokasi dana zakat adalah menolong orang yg terlilit hutang. Sehingga secara riil zakat juga kemudian menekan tingkat pengangguran.

\section{SIMPULAN}

Zakat merupakan instrumen keuangan Islam yang memiliki potensi sangat besar. Diperlukan upaya optimalisasi pengelolaan zakat agar dapat mencapai realisasi potensi yang diharapkan. Optimalisasi pengelolaan zakat tersebut akan menjadikan zakat berperan lebih optimal dalam mengatasi berbagai permasalahan ekonomi. Seperti masalah kemiskinan, kesenjangan, hingga pengangguran. Dengan begitu zakat dapat lebih dioptimalkan sebagai instrumen redistribusi pendapatan, serta instrumen fiskal untuk mewujudkan kesejahteraan masyarakat yang lebih luas.

Berdasarkan penjabaran tersebut, penulis merekomendasikan agar para pengelola zakat dapat menjalankan pola manajemen zakat yang lebih efektif untuk 
mengoptimalkan realisasi potensi zakat. Selain itu, peran Pemerintah sangat diperlukan untuk menjadikan zakat sebagai instrumen fiskal serta sebagai instrumen redistribusi pendapatan yang berkeadilan.

\section{DAFTAR PUSTAKA}

Azharsyah Ibrahim. (2011). Maksimalisasi Zakat Sebagai Salah Satu Komponen Fiskal Dalam Sistem Ekonomi Islam. Jurisprudensi: Jurnal Syariah.

BI, D. E. dan K. S. (2016). Usaha Mikro Islami. Bank Indonesia.

Canggih, C. (2017). Potensi dan Realisasi Dana Zakat Indonesia. Al Uqud: Journal of Islamic Economics, 1(1), 14-26.

Chaniago, S. (2015). Pemberdayaan Zakat dalam Mengentaskan Kemiskinan. Jurnal Hukum Islam, 13(1), 47-56.

Chapra, U. (2001). Masa Depan Ilmu Ekonomi. Gema Insani Press.

Fadhilah, F., \& Widiastuti, T. (2018). Pengaruh Pelatihan Dan Modal Bergulir Baznas (Badan Amil Zakat Nasional) Jawa Timur Terhadap Pendapatan Usaha Mustahiq. Al-Uqud: Journal of Islamic Economics, 2(2), 183. https://doi.org/10.26740/al-uqud.v2n2.p183-197

Fajarudin, I. (2019). Kontribusi Zakat sebagai Pendapatan Negara dan Instrumen Penerimaan Pajak. Studi Interpretif, 2(1), 25-38.

Hafidhuddin, D. (2010). Zakat dalam Perekonomian Modern (2010th ed.). Gema Insani Press.

Nasution, M. E. (2006). Zakat dan Wakaf sebagai Pilar dalam Sistem Perekonomian Nasional. Iqtishaduna: Jurnal Ekonomi Dan Bisnis Islam, 2(3), 1-14.

Nuruddin. (2006). Zakat sebagai Instrumen Kebijakan Fiskal. Rajawali Press. Priyono, S. (2017). Zakat Sebagai Instrumen Dalam Kebijakan Fiskal. Al Mashlahah Jurnal Hukum Dan Pranata Sosial Islam, 125-142.

Puskas. (2018). Kemiskinan Masyarakat Pesisir Indonesia dan Program Pemberdayaan Zakat. Baznas.

Puskas Baznas. (2019a). Pengaruh Zakat terhadap Perekonomian Makro Indonesia.

Puskas Baznas. (2019b). Zakat Outlook 2019 (Issue December 2018).

Qardhawi, Y. (2011). Hukum Zakat. Litera Antarnusa.

Rini, N., Huda, N., Putra, P., \& Mardoni, Y. (2017). PERAN DANA ZAKAT DALAM MENGURANGI KETIMPANGAN PENDAPATAN DAN KEMISKINAN. Ekuitas: Jurnal Ekonomi Dan Keuangan, 1(February), 108-127. https://doi.org/10.24034/j25485024.y2013.v17.i1.2230

Rohim, A. N. (2018). Maximizing Utility And Distributing Income Equitably: Islamic Economics Journal, 4(2), 155-180.

Rohim, A. N. (2019). Optimalisasi Penghimpunan Zakat Melalui Digital 
Fundraising. Al-Balagh : Jurnal Dakwah Dan Komunikasi, 4(1), 59-90. https://doi.org/10.22515/balagh.v4i1.1556

Sabiq, S. (2009). Fiqih Sunnah. Pena Pundi Aksara.

Soekarni, \& Muhammad. (2008). Investasi Syariah, implementasi, Konsep, dan Pernyataan Empirik. Kreasi Wacana.

Waluya, A. H. (2017). FIKIH ZAKAT SIMPANAN DI BANK DAN HUKUMHUKUMNYA. Al-Uqud : Journal of Islamic Economics, 1(2), 156-182. 